\title{
PENGARUH BULLYING TERHADAP KONSEP DIRI REMAJA DI SMK KESEHATAN KENDEDES MALANG
}

\author{
Siti Kholifah \\ Program Studi S1 IImu Keperawatan STIKes Kendedes Malang \\ E-mail :kholifah71@yahoo.co.id
}

\begin{abstract}
Bullying is a social problem that is often found among school children. This phenomenon continues to increase in numbers in Indonesia. Weak supervision from parents, educators, and the community is one of the factors causing the outbreak of bullying in the school environment, in addition to the fact that victims do not dare to fight or report. This has resulted in cases of bullying that can not be handled properly so that it gives the impact of depression, feelings of worthless and unaccepted, and changes in the victim's self-concept. This study aims to analyze the effect of bullying on adolescent selfconcept at Kendedes Health Vocational School. The design used was observational analytic with cross sectional study approach. The study was conducted at Kendedes Health Vocational School with a sample of 56 students selected using purposive sampling techniques. Analysis of data using linear regression. The results showed that bullying had an influence on adolescent self-concept $(r=0.242)$, with an effect of $5.8 \%(R$ Square $=0.058)$. This means that self-concept is influenced by $94.2 \%$ by other variables not examined. It takes attention and awareness of the school and students to avoid cases of bullying in schools. Further research is expected to strengthen the results of this study.
\end{abstract}

\section{Keywords : bullying, self-concept, adolescent}

Abstrak : Bullying merupakan salah satu masalah sosial yang banyak ditemukan di kalangan anak sekolah. Fenomena ini terus meningkat angkanya di Indonesia. Lemahnya pengawasan dari orang tua, pendidik, dan masyarakat menjadi salah satu faktor penyebab merebaknya kasus bullying di lingkungan sekolah, selain kenyataan bahwa korban tidak berani melawan atau melapor. Hal ini mengakibatkan kasus bullying tidak dapat tertangani dengan baik sehingga memberikan dampak depresi, perasaan tidak berharga dan tidak diterima, serta perubahan konsep diri korban. Penelitian ini bertujuan untuk menganalisis pengaruh bullying terhadap konsep diri remaja di SMK Kesehatan Kendedes Malang. Desain yang digunakan adalah observasional analitik dengan pendekatan cross sectional study. Penelitian dilaksanakan di SMK Kesehatan Kendedes Malang dengan jumlah sampel 56 siswa yang dipilih menggunakan teknik purposive sampling. Analisa data menggunakan regresi linier. Hasil penelitian menunjukkan bahwa bullying memiliki pengaruh terhadap konsep diri remaja $(r=0,242)$, dengan pengaruh sebesar $5,8 \%(R$ Square $=0,058$ ). Hal ini berarti konsep diri dipengaruhi sebesar $94,2 \%$ oleh variabel lain yang tidak diteliti. Diperlukan perhatian dan kesadaran pihak sekolah serta siswa untuk menghindari kasus bullying di sekolah. Penelitian lanjutan sangat diharapkan untuk menguatkan hasil penelitian ini.

\section{Kata Kunci : bullying, konsep diri, remaja}

\section{PENDAHULUAN}

Bullying merupakan salah satu masalah sosial yang banyak ditemukan di kalangan anak sekolah. Hampirsetiap anak sekolah pernah mengalami suatu bentuk perlakuan tidakmenyenangkan dari anak lain yang lebih tua atau lebih kuat (Krahe, 2005).Kebanyakan perilaku bullying terjadi secara tersembunyi (covert) dan sering tidak dilaporkan sehingga kurang disadari oleh kebanyakan orang (Glew et al, 2000). Selain itu, bentuk bullying yang sederhana seperti memanggil nama seseorang dengan bukan nama sebenarnya, seringkali hanya dianggap sebagai candaan sehingga tidak banyak orang yang menyadari (Khoirunisa, 2015).
Fenomena bullying terus meningkat angkanya di Indonesia. Menurut data Komisi Perlindungan Anak Indonesia (KPAI), sejak tahun 2011 hingga 2016 ditemukan sekitar 253 kasus bullying, terdiri dari 122 anak yang menjadi korban dan 131 anak yang menjadi pelaku. Data tersebut selaras dengan data Kementerian Sosial yang menunjukkan bahwa sebanyak 12,1\% kasus yang ditangani Kementerian Sosial merupakan kasus bullying. Jumlah tersebut tidak termasuk kasus bullying yang tidak dilaporkan.

Lemahnya pengawasan dari orang tua, pendidik, dan masyarakat menjadi salah satu faktor penyebab merebaknya kasus bullying di lingkungan sekolah yang terjadi pada anak-anak dan remaja. Selain 
itu, korban bullying juga tidak berani melawan atau melapor kepada orang lain karena mendapat ancaman dari pelaku. Maka tidak jarang kasus bullying tidak dapat tertangani dengan baik (Khoirunisa, 2015).

Bullying dapat mengakibatkan dampak yang sangat serius. Pada tahun 2012 sampai 2015, terdapat lima kasus tindakan atau percobaan bunuh diri yang dilakukan oleh korban bullying. Namun bunuh diri tidak menjadi satu-satunya dampak bullying, banyak korban bullying yang masih bertahan hidup walau harus menanggung luka batin. Pada siswa usia sekolah korban bullying dapat mengalami trauma, phobia sekolah, tidak percaya diri, pemurung, pendiam, penakut, tertutup, prestasi menurun, dan lain sebagainya. Selain itu, bullying juga dapat memberikan dampak depresi, merasa dirinya tidak berharga dan tidak diterima di masyarakat pada masa dewasanya serta dapat berpengaruh pada konsep diri yang dimilikinya (Khoirunisa, 2015).

Konsep diri merupakan aspek penting dalam diri seseorang, karena konsep diri merupakan acuan (frame of reference) dalam berinteraksi dengan lingkungan (Agustini, 2006). Seseorang dapat mengevaluasi persepsi terhadap dirinya sendiri melalui konsep diri. Pada diri remaja, banyak terjadi perubahan-perubahan baik fisik maupun psikisnya yang dapat berpengaruh pada konsep dirinya. Selain karena perubahan dalam dirinya, konsep diri juga dipengaruhi oleh pengalaman dari lingkungan sekitarnya. Pengalaman lingkungan sekitar yang tidak sesuai dengan keadaan dirinya, dapat menimbulkan konfik pada diri remaja. Remaja yang tidak dapat menyelesaikan konflik tersebut dengan baik maka akan terbentuk konsep diri yang negatif. Remaja yang menjadi korban bullying mendapatkan konflik pada diri dan lingkungannya, sehingga kemungkinan akan mempengaruhi konsep dirinya (Khoirunisa, 2015).

Orang yang memiliki konsep diri positif adalah orang yang mampu mengenali dan menerima dirinya apa adanya, cenderung memiliki sifat rendah hati dan memiliki harapan yang realistis dan harga diri yang tinggi. Sedangkan konsep diri negatif berarti seseorang memberi penilaian dan pandangan kepada dirinya secara negatif atau rendah, dan cenderung merasa tidak disenangi orang lain serta mudah putus asa. Konsep diri positif akan mempengaruhi perilakunya menjadi positif dan konsep diri negatif juga akan mempengaruhi perilakunya yang cenderung melakukan tindakan yang negatif atau tindakan yang kurang baik (Stuart \& Laraia, 2013).

Hasil studi pendahuluan di SMK Kesehatan Kendedes Malangmenunjukkan bahwa sebagian besar siswa tidak sepenuhnya menyadari bahwa tindakan yang dilakukan termasuk dalam perilaku bullying. Bentuk bullying yang paling banyak dilakukan adalah bullying secara verbal, seperti: mengolok, mengejek, dan memanggil dengan nama yang tidak semestinya. Siswa juga tidak memahami dampak dari perilaku bullying yang dilakukan terhadap korban. Data menunjukkan bahwa 6 dari 10 siswa SMK Kesehatan Kendedes pernah menjadi pelaku maupun korban bullying di sekolah. Berdasarkan fenomena tersebut, peneliti tertarik untuk mengkaji lebih jauh mengenai pengaruh bullying terhadap konsep diri remaja di SMK Kesehatan Kendedes Malang.

\section{METODE PENELITIAN}

Penelitian ini menggunakan desain observasional analitik dengan pendekatan cross-sectional study. Responden adalah siswa SMK Kesehatan Kendedes Malang yang berjumlah 56 orang yang didapatkan dengan metode purposive sampling. Penelitian dilaksanakan pada bulan Oktober 2019. Instrumen yang digunakan dalam penelitian ini adalah kuesioner bullying dan konsep diri yang telah diuji validitas dan reliabilitasnya. Analisis data yang digunakan dalam penelitian ini adalah analisis bivariat menggunakan uji regresi linier untuk mengetahui pengaruh bullying terhadap konsep diri remaja. 


\section{HASIL PENELITIAN}

Tabel 1 Karakteristik Responden Berdasarkan Usia

\begin{tabular}{ccc}
\hline Usia & Frekuensi (f) & Persentase (\%) \\
\hline 15 tahun & 12 & 21,4 \\
\hline 16 tahun & 4 & 7,1 \\
\hline 17 tahun & 22 & 39,3 \\
\hline 18 tahun & 15 & 26,8 \\
\hline 19 tahun & 3 & 5,4 \\
\hline Total & $\mathbf{5 6}$ & $\mathbf{1 0 0}$ \\
\hline
\end{tabular}

Berdasarkan tabel di atas diketahui bahwa responden terbanyak berusia 17 tahun sebesar $39,3 \%$ (22 orang).

Tabel 2 Karakteristik Responden Berdasarkan Kelas

\begin{tabular}{ccc}
\hline Usia & Frekuensi (f) & Persentase (\%) \\
\hline X & 15 & 26,8 \\
\hline XI & 7 & 12,5 \\
\hline XII & 34 & 60,7 \\
\hline Total & $\mathbf{5 6}$ & $\mathbf{1 0 0}$
\end{tabular}

Berdasarkan tabel di atas diketahui bahwa responden terbanyak adalah siswa kelas XII sebesar $60,7 \%$ (34 orang).

Tabel 3 Bullying pada Siswa SMK

\begin{tabular}{cccccc}
\hline & $\mathrm{n}$ & Median & Minimum-Maximum & Mean & SD \\
\hline Bullying & 56 & 24 & $14-35$ & 24,09 & 5,310 \\
\hline
\end{tabular}

Berdasarkan tabel di atas diketahui bahwa rata-rata skor bullying responden adalah 24,09 yang termasuk dalam bullying tingkat sedang.

Tabel 4 Konsep Diri pada Siswa SMK

\begin{tabular}{cccccc}
\hline & $\mathrm{n}$ & Median & Minimum-Maximum & Mean & SD \\
\hline $\begin{array}{c}\text { Konsep } \\
\text { Diri }\end{array}$ & 56 & 77,5 & $68-92$ & 78 & 6,135 \\
\hline
\end{tabular}

Berdasarkan tabel di atas diketahui bahwa rata-rata skor konsep diri responden adalah 78 yang termasuk dalam konsep diri positif.

Tabel 5 Koefisien

\begin{tabular}{cc|c|c|c}
\multicolumn{5}{c}{ Model Summary } \\
\hline Model & $\mathrm{R}$ & $\mathrm{R}$ Square & Adjusted R Square & Std. Error of the Estimate \\
\hline 1 &, $242^{\mathrm{a}}$ &, 058 &, 041 & 6,008 \\
\hline
\end{tabular}

a. Predictors: (Constant), Bullying

Berdasarkan tabel di atas diketahui bahwa nilai korelasi adalah 0,242. Nilai tersebut dapat diinterpretasikan bahwa hubungan variabel bullying dan konsep diri berada pada kategori lemah. Berdasarkan tabel di atas juga diperoleh nilai $R$ Square atau koefisien determinasi yang menunjukkan seberapa bagus model regresi yang dibentuk oleh interaksi variabel bebas dan variabel terikat. Nilai koefisien determinasi yang diperoleh adalah 5,8\%, sehingga dapat ditafsirkan bahwa variabel bullying memiliki pengaruh sebesar 5,8\% terhadap variabel konsep diri. 
Tabel 6 Uji Signifikansi

\begin{tabular}{|c|c|c|c|c|c|c|}
\hline \multicolumn{7}{|c|}{ ANOVA $^{\mathrm{a}}$} \\
\hline Model & & Sum of Squares & $\mathrm{df}$ & Mean Square & $\mathrm{F}$ & Sig. \\
\hline 11 & Regression & 120,917 & 1 & 120,917 & 3,350 &, $073^{b}$ \\
\hline & Residual & 1949,083 & 54 & 36,094 & & \\
\hline & Total & 2070,000 & 55 & & & \\
\hline
\end{tabular}

a. Dependent Variable: Konsep Diri

b. Predictors: (Constant), Bullying

Berdasarkan tabel diatas, diperoleh nilai Sig $>0,05$ sehingga dapat disimpulkan bahwa model persamaan regresi tidak memenuhi kriteria.

Tabel 7 Koefisien Regresi Sederhana

Coefficients $^{a}$

\begin{tabular}{|c|c|c|c|c|c|c|}
\hline \multirow{2}{*}{\multicolumn{2}{|c|}{ Model }} & \multicolumn{2}{|c|}{$\begin{array}{c}\text { Unstandardized } \\
\text { Coefficients }\end{array}$} & \multirow{2}{*}{$\begin{array}{c}\text { Standardized } \\
\text { Coefficients } \\
\text { Beta }\end{array}$} & \multirow[b]{2}{*}{$t$} & \multirow[b]{2}{*}{ Sig. } \\
\hline & & B & Std. Error & & & \\
\hline 1 & (Constant) & 84,727 & 3,762 & & 22,522 & ,000 \\
\hline & Bullying &,- 279 & 153 &,- 242 & $-1,830$ & 073 \\
\hline
\end{tabular}

a. Dependent Variable: Konsep Diri

Hasil penghitungan koefisien regresi sederhana di atas memperlihatkan nilai koefisien konstanta adalah sebesar 84,727dan koefisien variabel bebas $(X)$ adalah sebesar -0,279 sehingga diperoleh persamaan regresi $Y=84,727-0,279 X$.

\section{PEMBAHASAN}

\section{Bullying pada Remaja di SMK Kesehatan Kendedes Malang \\ Bullying merupakan perilaku negatif} berupa kekerasan fisik maupun kekerasan mental yang dilakukan secara berulang oleh seseorang atau sekelompok orang yang dapat merugikan orang lain (Wiyani, 2012). Kebanyakan perilaku bullying terjadi secara tersembunyi (covert) dan sering tidakdilaporkan sehingga kurang disadari oleh kebanyakan orang (Glew et al, 2000). Selain itu, bentuk bullying yang sederhana seperti memanggil nama seseorang dengan bukan nama sebenarnya, seringkali hanya dianggap sebagai candaan sehingga tidak banyak orang yang menyadari (Khoirunisa, 2015).

Hasil penelitian ini menunjukkan bahwa rata-rata skor bullying responden adalah 24,09 yang termasuk dalam bullying tingkat sedang. Hasil tersebut mencerminkan bahwa bullying sebenarnya banyak dialami oleh remaja namun kurang disadari. Terdapat beberapa alasan kasus bullying di sekolah ini kurang banyak mendapatkan perhatian hingga akhirnya jatuh korban. Menurut Prasetyo (2011), alasan utama adalah efeknya tidak tampak secara langsung, kecuali bullying dalam bentuk kekerasan fisik. Akan tetapi, ini pun tidak terendus karena banyak korban yang tidak mau melaporkan kekerasan yang dialaminya, entah karena takut, malu, diancam atau karena alasan-alasan lain.

Alasan kedua adalahbanyak kasus bullying yang secara kasatmata tampak seperti bercandaan biasa khas anak-anak sekolah atau remaja yang dikira tidak menimbulkan dampak serius. Ejekan-ejekan dan olok-olokan verbal termasuk dalam kategori ini. Banyak orangtua dan guru yang mengira bahwa teguran saja mungkin sudah cukup untuk menyelesaikan candaan tersebut. Padahal luka psikis dan emosional yang dialami korban kekerasan verbal itu jauh lebih dalam dan menyakitkan. Selain itu, sebagian orangtua dan guru masih belum memiliki pengetahuan yang memadai mengenai bullying dan dampaknya bagi kehidupan anak. Sehingga sebagian orangtua dan guru benar-benar tidak tahu bahwa ada masalah serius di sekitar mereka (Prasetyo, 2011).

Kasus bullying di sekolah dapat terjadi di semua jenjang pendidikan, mulai dari pendidikan dasar hingga pendidikan tinggi. Pada penelitian ini, responden yang dicakup berada dalam jenjang umur antara 
15-19 tahun, dengan usia terbanyak adalah 17 tahun sebesar $39,3 \%$ (22 orang). Pada rentang usia tersebut, responden tergolong sebagai remaja yang sedang mengalami masa peralihan dimana responden sudah tidak layak diperlakukan sebagai anak kecil, namun pertumbuhan fisik dan mentalnya pun belum layak dianggap dewasa. Pada fase ini remaja mengalami masa storm and stress, dimana kerap terjadi pergolakan emosi yang labil dengan diiringi pertumbuhan fisik yang pesat, serta perkembangan psikis yang sangat rentan terpengaruh oleh lingkungan. Remaja juga memiliki kecenderungan untuk menemukan jati dirinya, dan memiliki dorongan kuat untuk memperoleh pengakuan atau eksistensi dirinya terhadap orang lain (Yusuf, 2004). Hasil tersebut selaras dengan penelitian Marela dkk (2017) bahwa remaja SMA rentan terhadap kasus bullying dengan angka kejadian mencapai 49\%.

\section{Konsep Diri pada Remaja di SMK Kesehatan Kendedes Malang}

Hasil penelitian ini menunjukkan bahwa rata-rata skor konsep diri responden adalah 78 yang termasuk dalam konsep diri positif. Konsep diri positif merujuk pada kondisi penerimaan terhadap diri bukan kebanggaan yang besar tentang dirinya (Calhoun \& Acocella, 1990). Konsep diri positif mengarah pada kerendahan hati bukan keangkuhan dan keegoisan. Jadi orang yang memiliki konsep diri positif adalah orang yang memiliki perasaan berupa penerimaan tentang dirinya. la dapat menerima berbagai fakta yang berkaitan dengan dirinya dan menanggapi bahwa fakta-fakta yang ada pada dirinya bukan merupakan ancaman baginya.

Hasil penelitian ini selaras dengan penelitian Sutary dkk (2007) yang menunjukkan bahwa remaja pada umumnya mengenali konsep diri mereka dengan baik. Pada umumnya, mereka pun memiliki konsep diri yang positif. Hal itu tampak dari pandangan mereka tentang karakteristik diri yang berhubungan dengan sifat individu yang dalam anggapan, baik reponden perempuan, maupun laki-laki, memiliki sifat pemberani dan mudah bergaul. Mereka memandang kemampuan dirinya secara positif pula. Hal itu ditunjukkan dengan rasa percaya diri, optimis menghadapi masa depan. Berkaitan dengan kemampuan diri ini, para responden menyatakan aspirasi berupa cita-cita yang meliputi berbagai bidang. Responden juga menanggapi lingkungan secara positif. Lingkungan di luar mereka dalam pandangan mereka menyenangkan. Dengan pandangan yang positif ini, mereka pun menunjukkan sikap kolaboratif dengan lingkungan di sekitar mereka. Mereka pun punya motivasi dan tekad yang kuat dalam menghadapi tantangan kehidupan.

Konsep diri remaja dipengaruhi oleh beberapa faktor, yaitu pola asuh orangtua, teman sebaya dan peranan harga diri (Saraswati \& Sawitri, 2015). Penelitian Pardede (2008) menunjukkan bahwa faktor pola asuh orangtua merupakan faktor penentu utama konsep diri pada remaja. Pola asuh merupakan interaksi anak dan orang tua mendidik, membimbing, dan mendisiplinkan serta melindungi anak untuk mencapai kedewasaan sesuai dengan norma-norma yang ada dalam masyarakat (Edwards, 2006). Hal ini selaras dengan penelitian Harianti (2012) yang menyatakan bahwa terdapat hubungan yang signifikan antara pola asuh orangtua dengan konsep diri remaja di SMAN 11 Banda Aceh.

\section{Pengaruh Bullying terhadap Konsep Diri Remaja di SMK Kesehatan Kendedes Malang}

Hasil penelitian ini menunjukkan bahwa bullying berpengaruh terhadap konsep diri remaja, dengan pengaruh sebesar $5,8 \%$. Kekuatan pengaruh variabel bullying terbilang kecil, sehingga persamaan regresi yang didapatkan dalam penelitian ini tidak dapat digunakan untuk memprediksi konsep diri remaja. Hal ini juga berarti bahwa konsep diri dipengaruhi oleh faktor lain sebesar 94,2\%.

Konsep diri tidak berkembang dengan sendirinya, tetapi berkembang dengan adanya interaksi dengan orang yang lain, khususnya dengan lingkungan sosial. Menurut Calhaoun dan Acocella (1990), ketika lahir manusia tidak memiliki konsep diri, pengetahuan tentang dirinya sendiri, harapan terhadap dirinya sendiri, dan penilaian terhadap dirinya sendiri. Namun, secara perlahan-lahan seseorang mulai dapat membedakan "aku" dan "bukan aku". Kemajuan besar dalam perkembangan konsep diri terjadi ketika seseorang mulai menggunakan bahasa, 
yaitu sekitar umur satu tahun. Seseorang akan memperoleh informasi yang lebih banyak tentang dirinya dengan memahami perkataan orang lain. Terlebih lagi, ketika seseorang belajar berpikir dengan menggunakan kata-kata. Pada saat itulah, konsep diri, baik positif maupun negatif mulai terbentuk. Konsep diri tentu saja terus berkembang sepanjang hidup, tetapi cenderung berkembang sepanjang garis yang telah terbentuk pada awal masa kanak-kanak.

Teori tersebut menguatkan temuan dalam penelitian ini bahwa bullying hanya berpengaruh sebesar 5,8\% terhadap konsep diri remaja. Hal ini bermakna bahwa bullying yang dialami remaja saat menempuh pendidikan di SMA/K tidak serta merta merubah konsep dirinya menjadi negatif. Sejak awal masa kanak-kanak, konsep diri seseorang telah terbentuk melalui pola asuh yang dikembangkan oleh orangtuanya (Calhaoun \& Acocella, 1990). Orang tua merupakan kontak sosial yang paling awal dan paling kuat yang dialamai seseorang. Orang tua sangat berpengaruh terhadap diri anak. Orang tua merupakan pihak yang pertama ia kenal dan merupakan sumber informasi yang paling utama. Orang tua mengajarkan bagaimana menilai diri sendiri. Seiring bertambahnya usia seseorang, sumber pembentukan konsep diri tidak hanya berasal dari orangtuanya, tetapi juga teman sebaya atau masyarakat yang lebih luas.

Terdapat beberapa faktor lain yang dapat berpengaruh terhadap konsep diri remaja, yaitu: pola asuh orangtua, teman sebaya dan peranan harga diri (Saraswati \& Sawitri, 2015). Penelitian lain menunjukkan adanya faktor media massa dan budaya materialisme yang berpengaruh terhadap konsep diri remaja (Feliciano, 2012). Oleh karena itu diperlukan penelitian lanjutan untuk mengetahui faktor-faktor yang mempengaruhi konsep diri remaja dengan

\section{DAFTAR PUSTAKA}

Agustini, C. (2006). Perilaku Merokok Mahasiswa Ditinjau Dari Konsep Diri. Skripsi. Semarang: Fakultas Psikologi Unika Soegijapranata

Calhoun, J. F., \& Acocella, J. R. (1990). Psychology of Adjustment and Human mempertimbangkan beberapa faktor tersebut.

\section{KESIMPULAN}

Berdasarkan hasil penelitian ini dapat disimpulkan bahwa: 1) rata-rata skor bullying pada remaja di SMK Kesehatan Kendedes Malang adalah 24,09 yang termasuk dalam bullying tingkat sedang; 2) rata-rata skor konsep diri pada remaja di SMK Kesehatan Kendedes Malang adalah 78 yang termasuk dalam konsep diri positif; 3) bullying berpengaruh terhadap konsep diri remaja, dengan pengaruh sebesar $5,8 \%$.

\section{SARAN}

Berdasarkan hasil penelitian ini maka dapat disarankan: 1) Siswa SMK Kesehatan Kendedes Malang diharapkan dapat mengurangi atau menghindari perilaku bullying selama di sekolah karena dapat mempengaruhi konsep dirinya di kemudian hari. Selain itu, siswa diharapkan berani membuka diri dan meminta bantuan pada pihak sekolah apabila terjadi bullying di lingkungan sekolah; 2) Pihak sekolah (pengelola SMK Kesehatan Kendedes Malang) diharapkan lebih proaktif dalam melakukan pengawasan dan pembinaan terhadap siswanya sehingga siswa dapat terhindar dari bullying. Pihak sekolah dapat mengaktivasi Bimbingan Konseling untuk menangani kasus-kasus bullying yang terjadi di sekolah; 3) Penelitian ini diharapkan dapat dikuatkan dengan penelitian lanjutan dengan mempertimbangkan beberapa faktor lain yang dapat berkontribusi pada pembentukan konsep diri remaja. Selain itu, diperlukan modifikasi desain penelitian (secara retrospektif) untuk mendapatkan kualitas data yang lebih baik.

Relationship.New York: McGraw-Hill Publishing Company

Edwards, DC. (2006). Ketika Anak Sulit Diasuh: Panduan Orang tua Mengubah Masalah Perilaku Anak. Bandung : PT Mizan Pustaka 
Feliciano, D, J. (2012). Factors of Adolescence self concept: Mass Mediated, Peer and Family Communication, University of West Florida.

Glew, Rivara, \& Feudtner. (2000). Bullying: Children Hurting Children. Pediatrics in Review. Seattle: University of Washington

Harianti, M. (2012). Hubungan pola asuh orang tua dengan konsep diri remaja di SMAN 11 Banda Aceh.Jurnal Universitas Syiah Kuala.

Khoirunisa, R. (2015). Konsep diri remaja korban bullying. Jurnal Bimbingan dan Konseling. 10 (4)

Krahe, B. (2005). Perilaku Agresif: Buku Panduan Psikologi Sosial. Terjemahan:

Drs. Helly Prajitno Soetjipto, MA \& Dra. Sri Mulyantini Soetjipto. Yogyakarta: Pustaka Pelajar

Marela, G., Wahab, A., \& Marchira, C.R. (2017). Bullying verbal menyebabkan depresi pada remaja SMA di Kota Yogyakarta. Berita Kedokteran Masyarakat. 33(1)
Pardede. (2008). Konsep Diri Anak Jalanan Usia Remaja. Jurnal Psikologi Universitas Guna Darma.1(2)

Prasetyo, A. (2011). Bullying di Sekolah dan Dampaknya bagi Masa Depan Anak.Jurnal Pendidikan Islam. 1(4)

Saraswati, M.A., \& Sawitri, D.R. (2015). Konsep Diri dengan Kecenderungan Bullying pada Siswa Kelas XI SMK. Jurnal Empati. 4(4)

Stuart, GW., \& Laraia, MT. (2013). Principles and practice of psychiatric nursing. $10^{\text {th }}$ edition. St. Louis: Mosby Year Book

Sutary, K. Y. I., Lilis, N. A., \& Yulianeta. (2008). Konsep diri remaja dalam pengaktualisasian kemampuan kompetensinya. Jurnal Universitas Pendidikan Indonesia. 4(1)

Wiyani, A. (2012). Save our children from school bullying. Jogjakarta : Arruzz Media

Yusuf, S. (2004). Psikologi Perkembangan Anak dan Remaja. Bandung: Remaja Rosdakarya 